\title{
Sarcoma of breast, with particular reference to its origin from fibroadenoma
}

\author{
R. C. CURRAN AND O. G. DODGE \\ From the Departments of Pathology, St. Thomas's Hospital Medical School, \\ and Sheffield University
}

SYNOPSIS Thirty-nine sarcomas of breast are described. The patients' ages ranged from 26 to 78 years but most patients were middle-aged or elderly. Evidence is adduced that 16 of the tumours arose from pre-existing fibroadenomas and others very probably did so. Many tumours were adenosarcomas and one was a carcinosarcoma which preserved its structure in a lymph-node metastasis. Recurrences were mostly local, but a small group had a much graver prognosis. A pleomorphic and giant-cell structure usually meant a high degree of malignancy but the significance of cartilaginous or bony metaplasia, present in seven tumours, was less certain.

It is wise to regard all 'fibroadenomas' of the breast occurring in patients over 40 years of age as at least potentially malignant, and these should be examined histologically with care, particularly since sarcomatous change may be present in one part only and therefore easily overlooked.

This paper reviews those cases diagnosed as sarcoma of the breast in three large teaching hospitals during the past 25 years. Although this type of tumour has proved to be comparatively rare, in that only 39 cases were found, the most striking fact to emerge was the close relationship which often existed between the sarcoma and a pre-existing fibroadenoma. The presence or absence of this relationship provided in fact a useful way of classifying the tumours into (1) malignant fibroadenomas, in which a new growth of sarcomatous, adenosarcomatous, or even carcinosarcomatous tissue had developed from a fibroadenoma; (2) sarcomas with included epithelial structures (adenosarcomas), in which a fibroadenomatous origin was less certain; and (3) 'pure' sarcomas, which had no detectable link with preexisting fibroadenomas.

Two features of this scheme of classification should be made clear. First it is exclusively histological, since clinical assessment of the nature and potentialities of breast tumours consisting largely of connective tissue is rather inexact, probably because surgeons rarely encounter them; and secondly, there is no hard and fast division between the groups and the distinction between groups 1 and 2 is particularly tenuous.

Received for publication 3 July 1961

${ }^{1}$ Present address: Department of Pathology, Makerere College, P.O. Box 2072, Kampala, Uganda

\section{RESULTS}

The main features of the 39 cases are listed in Tables I, II, and III.

\section{MALIGNANT FIBROADENOMAS}

The malignant fibroadenomas (Table I) are 16 in number. Basically, these are fibroadenomas with a stroma which has become sarcomatous; 10 of the fibroadenomas are mainly intracanalicular ('giant' fibroadenomas) (Figs. 1 and 2) and six mainly pericanalicular in structure. Seven of the cases are both histologically and clinically malignant; six are histologically malignant; and in three cases (Nos. 2, 3, and 4) the evidence of malignancy is largely clinical. In some of the 13 tumours showing histological malignancy, the sarcomatous part of the tumour is relatively small and it could have been missed if only one or two sections from each tumour had been examined. Of the 16 patients, four had recurrences in the operation site; one of these four later died of sarcomatosis, and so did two other women. Only one person developed secondaries in the axillary lymph nodes and her tumour was, significantly, a mixture of adenocarcinomatous and sarcomatous elements (Case 15). Although most of the new growth is sarcomatous, the epithelium too is partaking in the process in several tumours and 
TABLE I

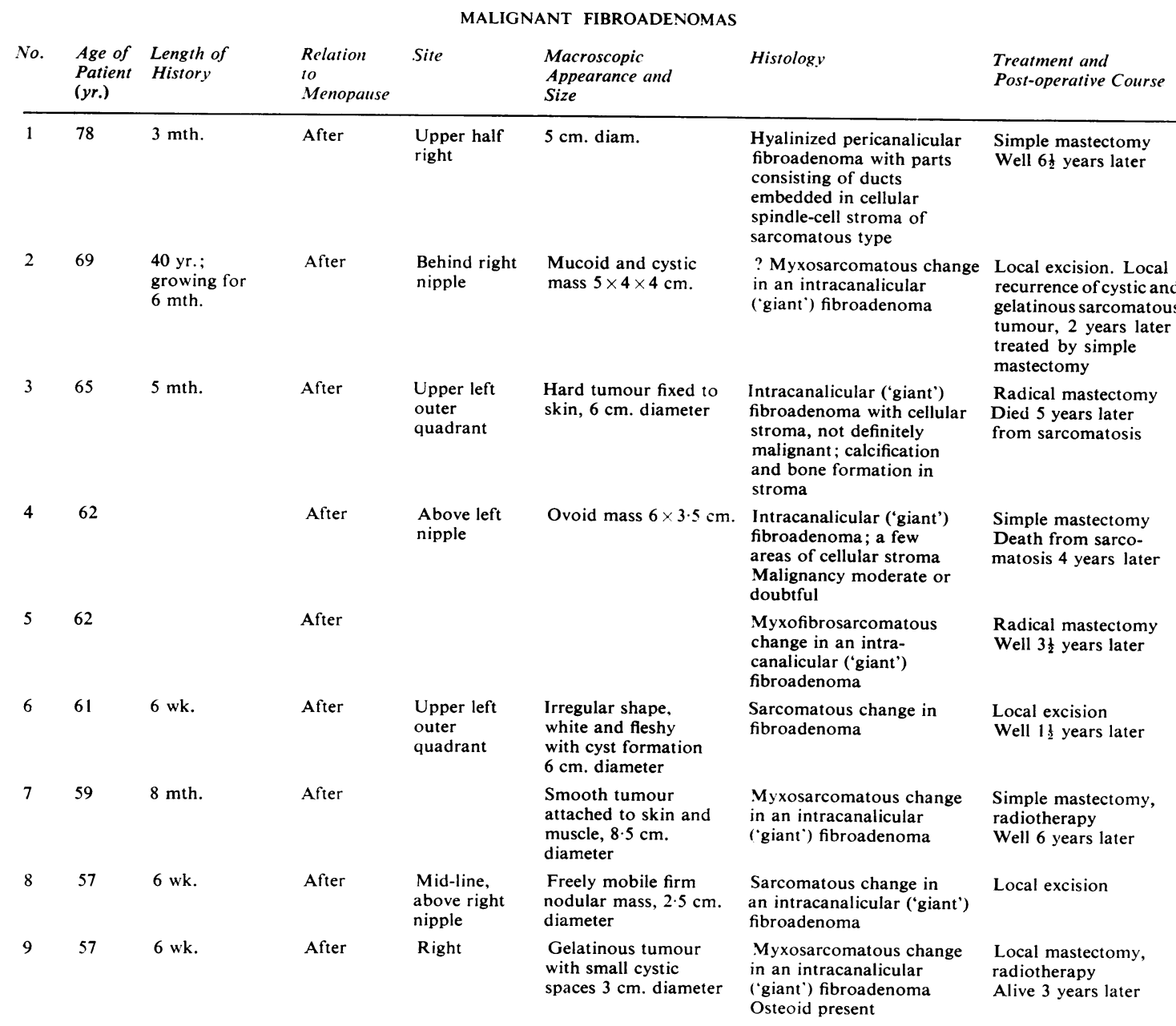

forming abnormal glands: these tumours are therefore adenosarcomas.

\section{ADENOFIBROSARCOMA}

Scattered throughout the sarcomatous tissue of adenofibrosarcomas (Table II) are numerous glandular structures. In a few tumours these are scanty (Cases 22 and 24) and it might be postulated that they are pre-existing ducts 'caught up' in the sarcomatous tissue. But in most of the tumours their close integration with the sarcomatous element suggests that the tumours are true adenosarcomas. There is no benign fibroadenomatous tissue, however, and therefore a convincing fibroadenomatous origin is lacking. All the same, the readiest explanation is that these neoplasms are pericanalicular fibroadenomas which have become malignant.

Of the 12 patients, three had local recurrences and another developed a solitary lung metastasis four and a half years after resection of the primary.

\section{'PURE' SARCOMA}

The 'pure' sarcomas (Table $\mathbf{H I}$ ), 11 in number, are malignant mesenchymal tumours in which no epithelial structures can be found. In two patients there was local recurrence which was successfully treated. Three died of sarcomatosis and two others may have died from the same cause. One is still alive but has multiple secondaries. 
TABLE 1-cont.

\begin{tabular}{|c|c|c|c|c|c|c|c|}
\hline No. & $\begin{array}{l}\text { Age of } \\
\text { Patient } \\
(y r .)\end{array}$ & $\begin{array}{l}\text { Length of } \\
\text { History }\end{array}$ & $\begin{array}{l}\text { Relation } \\
\text { to } \\
\text { Menopause }\end{array}$ & Site & $\begin{array}{l}\text { Macroscopic } \\
\text { Appearance and } \\
\text { Size }\end{array}$ & Histology & $\begin{array}{l}\text { Treatment and } \\
\text { Post-operative Course }\end{array}$ \\
\hline 10 & 56 & $10 \mathrm{wk}$. & After & $\begin{array}{l}\text { Upper right } \\
\text { outer } \\
\text { quadrant }\end{array}$ & $\begin{array}{l}\text { Well encapsulated } \\
\text { mucoid, } 6 \mathrm{~cm} \text {. } \\
\text { diameter }\end{array}$ & $\begin{array}{l}\text { Sarcomatous change in } \\
\text { an intracanalicular } \\
\text { fibroadenoma }\end{array}$ & $\begin{array}{l}\text { Simple mastectomy } \\
\text { Local recurrence of } \\
\text { 'adenosarcoma' } 5 \\
\text { years later, easily } \\
\text { resected, very similar } \\
\text { to primary in histology }\end{array}$ \\
\hline 11 & 50 & $2 \mathrm{yr}$. & After & & $\begin{array}{l}\text { Large, irregular, } \\
\text { somewhat translucent } \\
\text { and gelatinous mass } \\
(10 \times 14 \mathrm{~cm} .) \text { showing } \\
\text { extensive necrosis and } \\
\text { some areas of } \\
\text { haemorrhage }\end{array}$ & $\begin{array}{l}\text { Sarcomatous change in } \\
\text { an intracanalicular ('giant') } \\
\text { fibroadenoma }\end{array}$ & Local mastectomy \\
\hline 12 & 45 & $5 \mathrm{mth}$. & $?$ & $\begin{array}{l}\text { Upper left } \\
\text { outer } \\
\text { quadrant }\end{array}$ & Over $4 \frac{1}{2} \mathrm{~cm}$. diameter & $\begin{array}{l}\text { Sarcomatous change in } \\
\text { fibroadenoma }\end{array}$ & $\begin{array}{l}\text { Local excision, then } \\
\text { radical mastectomy } \\
\text { Well } 1 \text { year later }\end{array}$ \\
\hline 13 & 43 & $6 \mathrm{mth}$. & Before & Left & $\begin{array}{l}\text { Lobulated gelatinous } \\
\text { mass filling breast }\end{array}$ & $\begin{array}{l}\text { Intracanalicular ('giant') } \\
\text { fibroadenoma with cellular } \\
\text { stroma of moderate } \\
\text { malignancy }\end{array}$ & $\begin{array}{l}\text { Local excision of } \\
\text { tumour } \\
\text { Massive local recur- } \\
\text { rence of adenosarcoma } \\
\text { after } 17 \text { months } \\
\text { Recurrence excised } \\
\text { Well } 2 \text { years after first } \\
\text { admission }\end{array}$ \\
\hline 14 & 40 & $1 \mathrm{yr}$. & Before & Right & $\begin{array}{l}\text { Encapsulated } 8 \mathrm{~cm} . \\
\text { diameter }\end{array}$ & $\begin{array}{l}\text { Sarcomatous change in } \\
\text { fibroadenoma }\end{array}$ & $\begin{array}{l}\text { Local excision and } \\
\text { radiotherapy } \\
\text { Well } 2 \frac{1}{4} \text { years later }\end{array}$ \\
\hline 15 & 38 & 2 yr. & Before & Left & $\begin{array}{l}\text { Lobulated encapsu- } \\
\text { lated mass with } \\
\text { mucoid and cystic } \\
\text { areas } \\
13 \mathrm{~cm} \text {. diameter } \\
(700 \mathrm{~g} .)\end{array}$ & $\begin{array}{l}\text { Sarcomatous change in } \\
\text { fibroadenoma }\end{array}$ & $\begin{array}{l}\text { Simple mastectomy } \\
\text { Recurrence in scar } \\
\text { (sarcoma) and axilla } \\
\text { (carcinoma and } \\
\text { sarcoma) after } 9 \\
\text { months } \\
\text { Died } 2 \text { years after first } \\
\text { operation with axillary } \\
\text { and lung secondaries }\end{array}$ \\
\hline 16 & 35 & & Before & Left & $\begin{array}{l}\text { Rubbery, partly, } \\
\text { encapsulated greyish } \\
\text { white mass } \\
6 \times 4 \times 2 \mathrm{~cm} \text {. }\end{array}$ & $\begin{array}{l}\text { Sarcomatous change in } \\
\text { an intracanalicular } \\
\text { ('giant') fibroadencma }\end{array}$ & $\begin{array}{l}\text { Local excision } \\
\text { Post-operative radic- } \\
\text { therapy }\end{array}$ \\
\hline
\end{tabular}

\section{ILLUSTRATIVE CASES}

\section{MALIGNANT FIBROADENOMAS}

WITH LOCAL RECURRENCE A woman of 43 (Case 13, Table I) presented with a lump in the left breast which had been growing for 6 months. She was married but had no children. Menstruation was normal. A firm mass almost filled the breast but it was not attached deeply or to the skin. Local excision was performed. The excised tumour measured $7 \times 6 \times 5 \mathrm{~cm}$. with outlying satellites up to $0.5 \mathrm{~cm}$. diameter. Parts of the tumour had the structure of a 'giant' intracanalicular fibroadenoma (Fig. 3), but in spite of histological evidence of malignancy (Fig. 4), the lesion was diagnosed as benign. However, the patient returned 17 months later with a massive recurrence at the operation site. Simple mastectomy was performed. The tumour's structure still resembled that of the primary but the connective tissue component now showed a much more sinister histological pattern which was frankly sarcomatous (Fig. 5). Numerous glandular structures mingled with the sarcomatous tissue, and, interestingly, occasional mitotic figures were present among the epithelial cells (Fig. 5). The patient was well and free from recurrence six months after the second operation.

This case probably illustrates the reluctance of pathologists to label a 'fibroadenoma' malignant. The tumour was very large and there was histological evidence of mitotic activity and of local invasion, but the possibility of malignancy was not considered. However, there was fairly rapid local recurrence of adenosarcoma. 


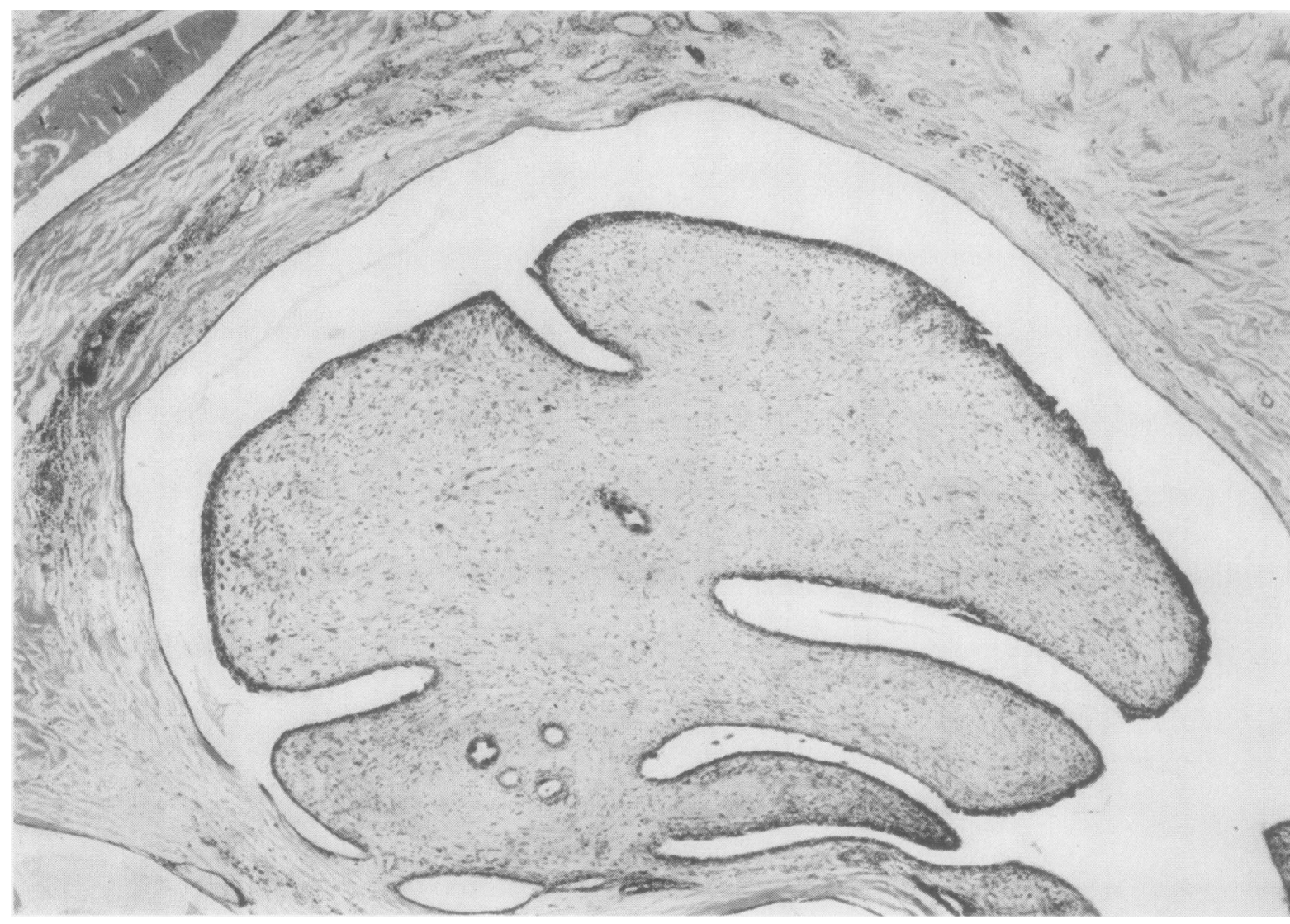

FIG. 1. Case 8, Table I. The large intracanalicular process, typical of the true 'giant' fibroadenoma, consists of sarcomatous tissue covered by a thick layer of hyperplastic epithelial cells. The cystic space which the polypoid mass fills is lined by a very attenuated epithelium. Note the compressed normal breast at the top. (Haematoxylin and eosin $\times 60$.)

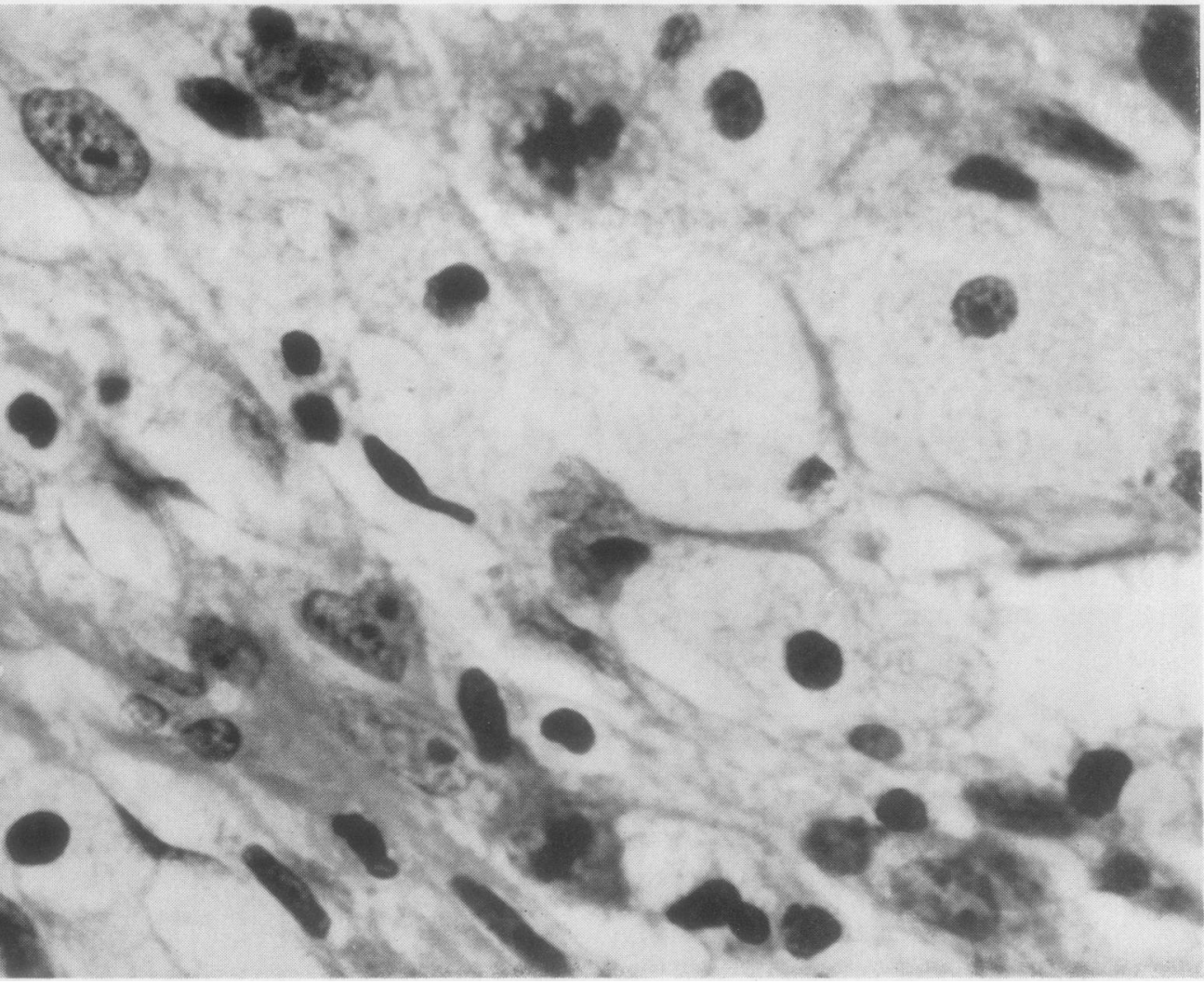

FIG. 2. Case 8, Table $I$. This is a sarcomatous area. The cells show great p?omorphism; most are spingalle cells but some are lärge round pale cells (botibom right). There are two miteses in this field (top centre and bottom centre). (Faematoxylin and eosin $\rightarrow$ 800.) 


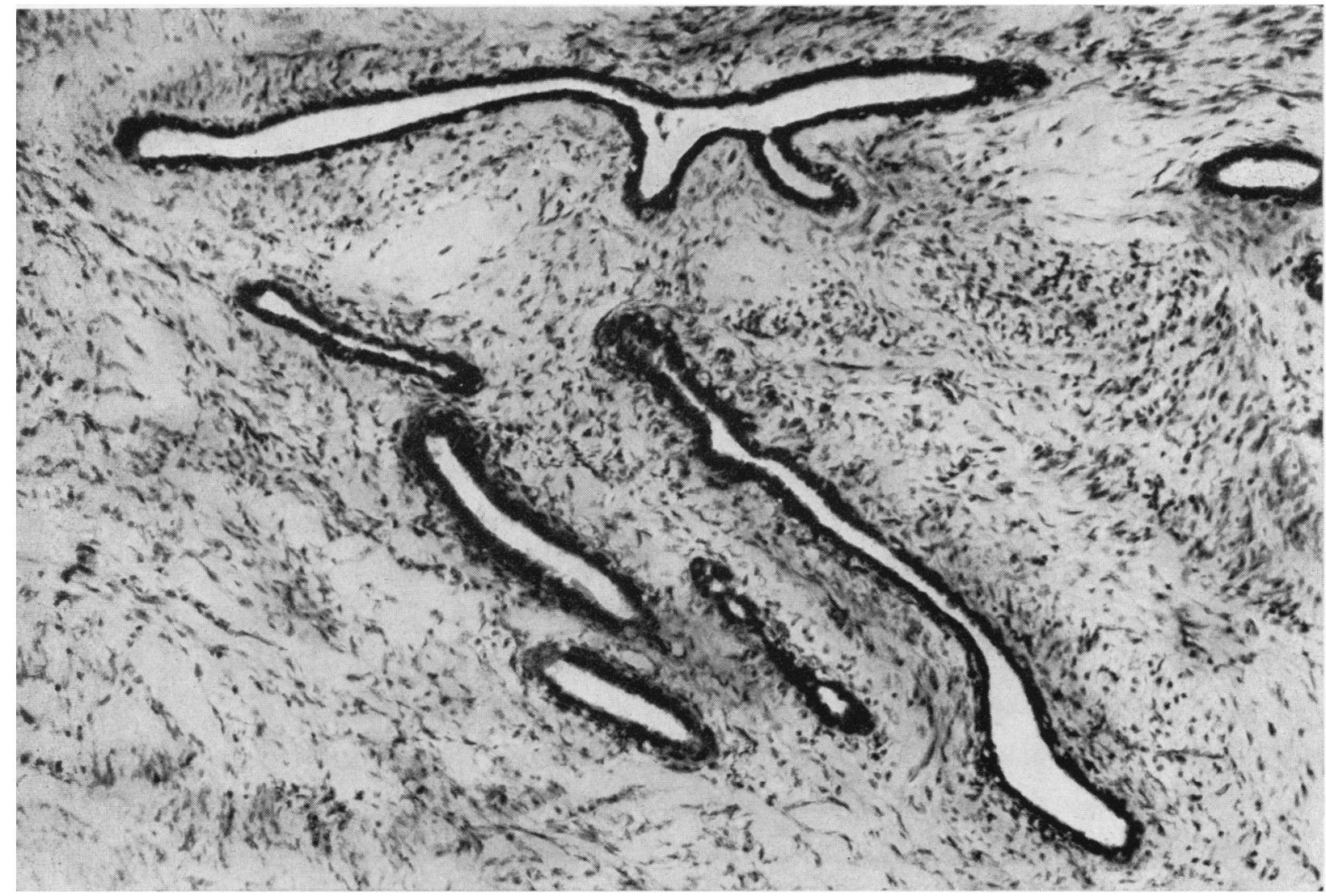

FIG. 3. Case 13, Table I. Numerous irregular glands are scattered throughout the sarcomatous tissue and the pattern of this part of the adenosarcoma is therefore 'pericanalicular'. (Haematoxylin and eosin $\times 100$.)

WITH BOTH MESENCHYMAL AND EPITHELIAL ELEMENTS IN A LYMPH NODE METASTASIS A woman of 38 (Case 15, Table I) stated that she had had a lump in the left breast for two years. She had one child, age 7; lactation had been normal. On examination the breast was filled by a freely mobile cauliflower-like mass and axillary lymph nodes were enlarged. Simple mastectomy was performed. The tumour, $13 \mathrm{~cm}$. in diameter, weighed $700 \mathrm{~g}$. It was lobulated and encapsulated, but there were areas of mucoid and cystic degeneration and of haemorrhage. The more solid areas were soft and pink. Histology showed that the tumour, though basically an intracanalicular fibroadenoma, consisted in places of a complex mixture of fibromyxosarcomatous tissue and abnormal epithelial structures; these consisted of small acini and islands of atypical epithelial cells, sometimes of a squamous cell type (Fig. 6 ). The patient was readmitted nine months later with a lump the size of a marble at the upper end of the mastectomy scar; there were also two masses of enlarged axillary lymph nodes. These lesions were resected. Histologically, the nodule in the scar had the same structure as the carcinosarcomatous part of the original tumour. The lymph nodes were more or less completely replaced by tumour; in some, this was a remarkably well-differentiated spindle-cell sarcoma (Fig. 7) but in one the deposit was a mixture of sarcomatous tissue and malignant epithelial acini (Fig. 8). Despite post-operative radiotherapy, there were further recurrences in the scar and a fungating mass had developed in the axilla 14 months later. A large rounded secondary deposit was also present in the right lung. She died a month later, two years after the first operation. There was no necropsy.

This tumour was unusual for two main reasons. First, it seemed to be still encapsulated at the first operation, even though it was unusually large. Second, the histological structure of this primary growth was a mixture of sarcoma and carcinoma; and even more surprisingly, this structure was later perpetuated in the secondaries in the axillary nodes. The carcinomatous element may have been the reason for the lymphatic spread, since in none of the 


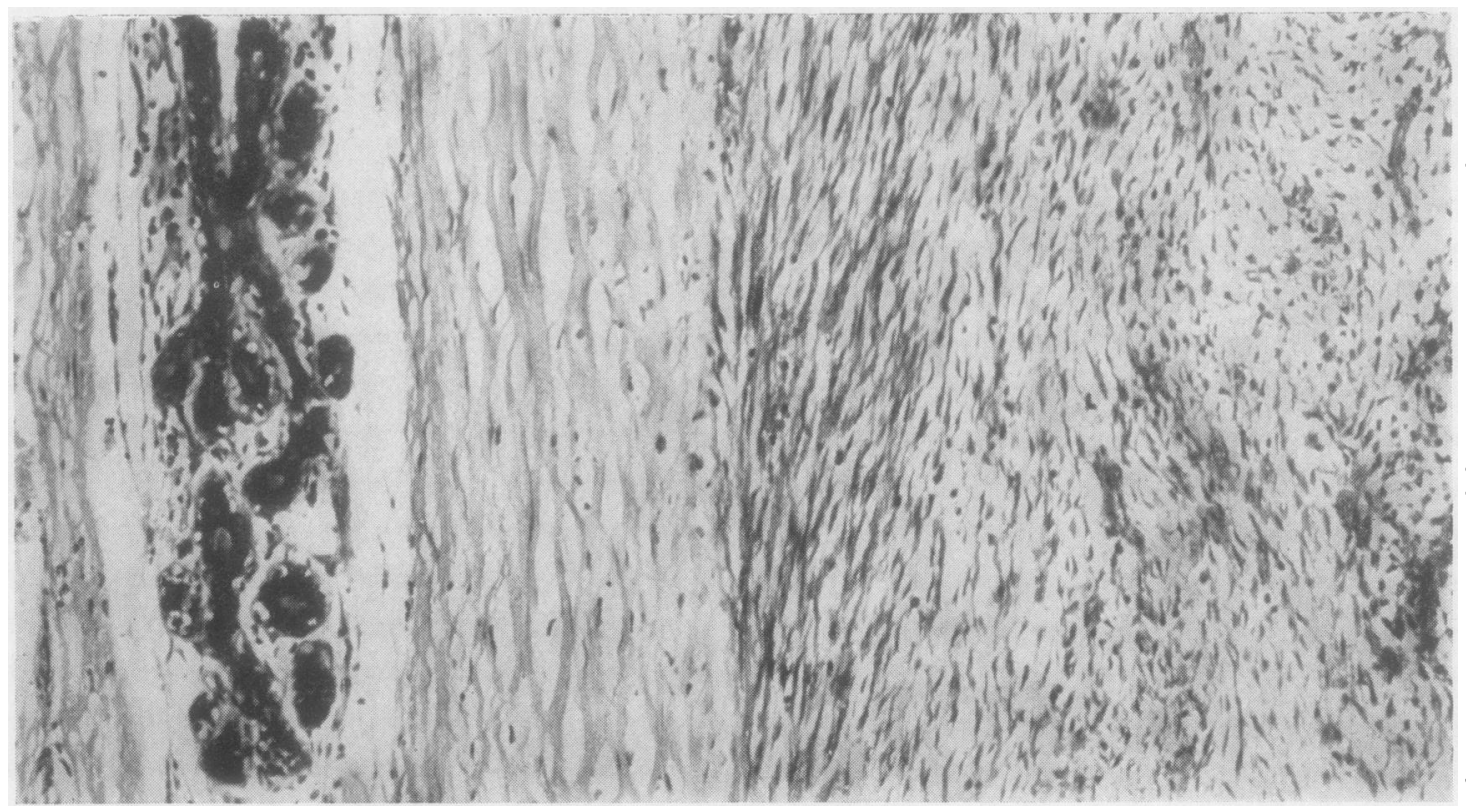

FIG. 4. Case 13, Table I. Well-differentiated fibrosarcomatous tissue (left) is separated by a dense fibrous capsule from a compressed normal breast lobule (right). The capsule was present round only part of the tumour. (Haematoxvlin and eosin $\times 120$.

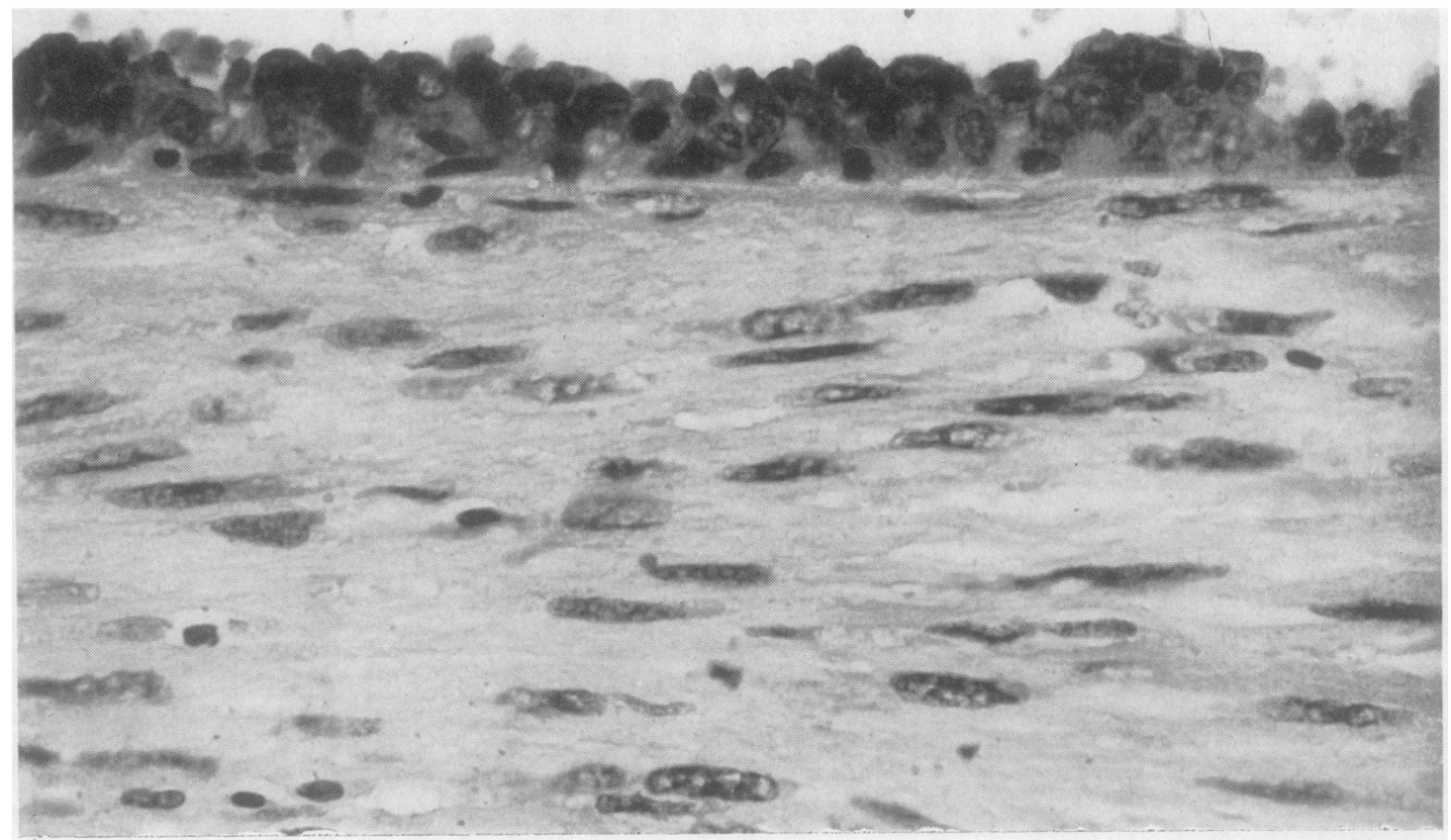

FIG. 5. Case 13, Table I. Adenosarcomatous recurrence of tumour shown in Fig. 4. This is a wel-differentiated and fibrous part of the sarcomatous tissue. An elongated glandular space runs along the top; its thick epithelial lining contains one cell in prophase (top centre). (Haematoxylin and eosin $\times 600$.) 


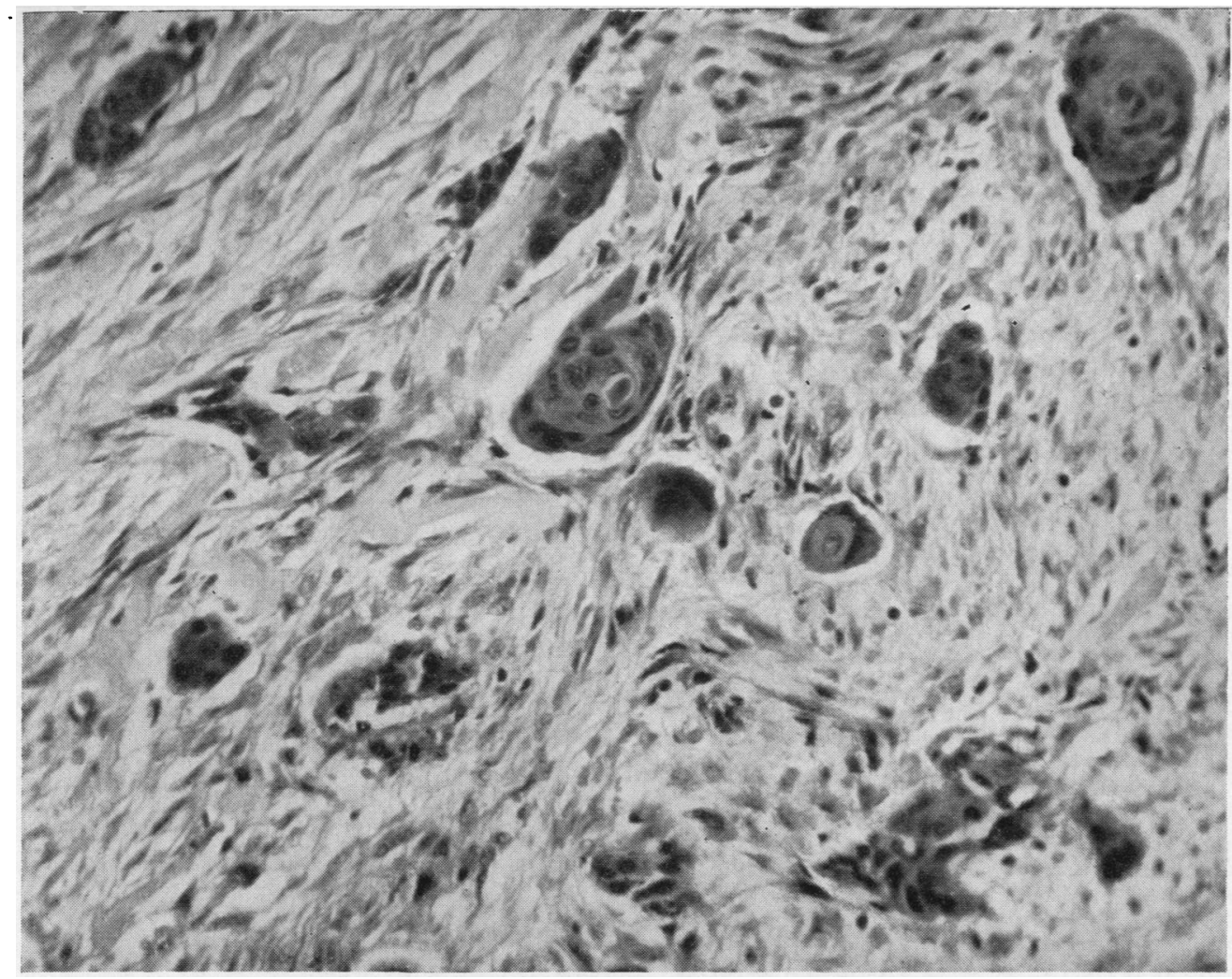

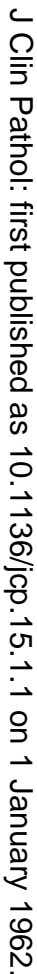

FIG. 6. Case 15, Table I. The sarcomatous tissue is well-differentiated and fibrous. The small clumps of epithelial cells show squamous metaplasia. (Haematoxylin and eosin $\times 160$.)

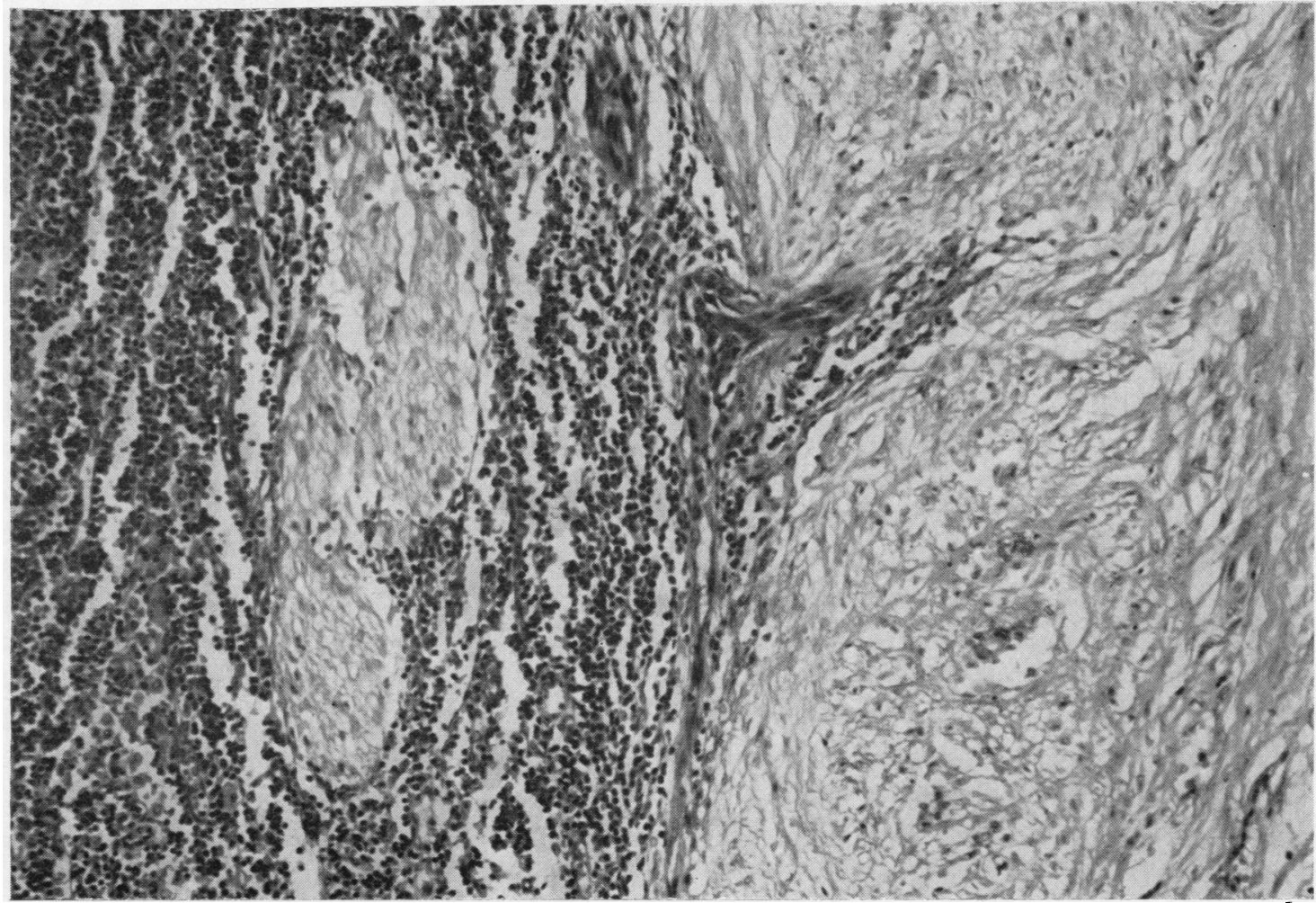

FIG. 7. Case 15, Table I. Sarcomatous recurrence in an axillary lymph node of the tumour shown in Fig. 6. On the left is the main mass of well-differentiated and remarkably fibrous sarcomatous tissue. Penetrating the lymphoid tissue (right) ahead of it, and conpletely surrounded by lymphocytes, is a smaller deposit of sarcoma. (See also Fig. 8.) (Haematoxylin and eosin $\times 85$.) 


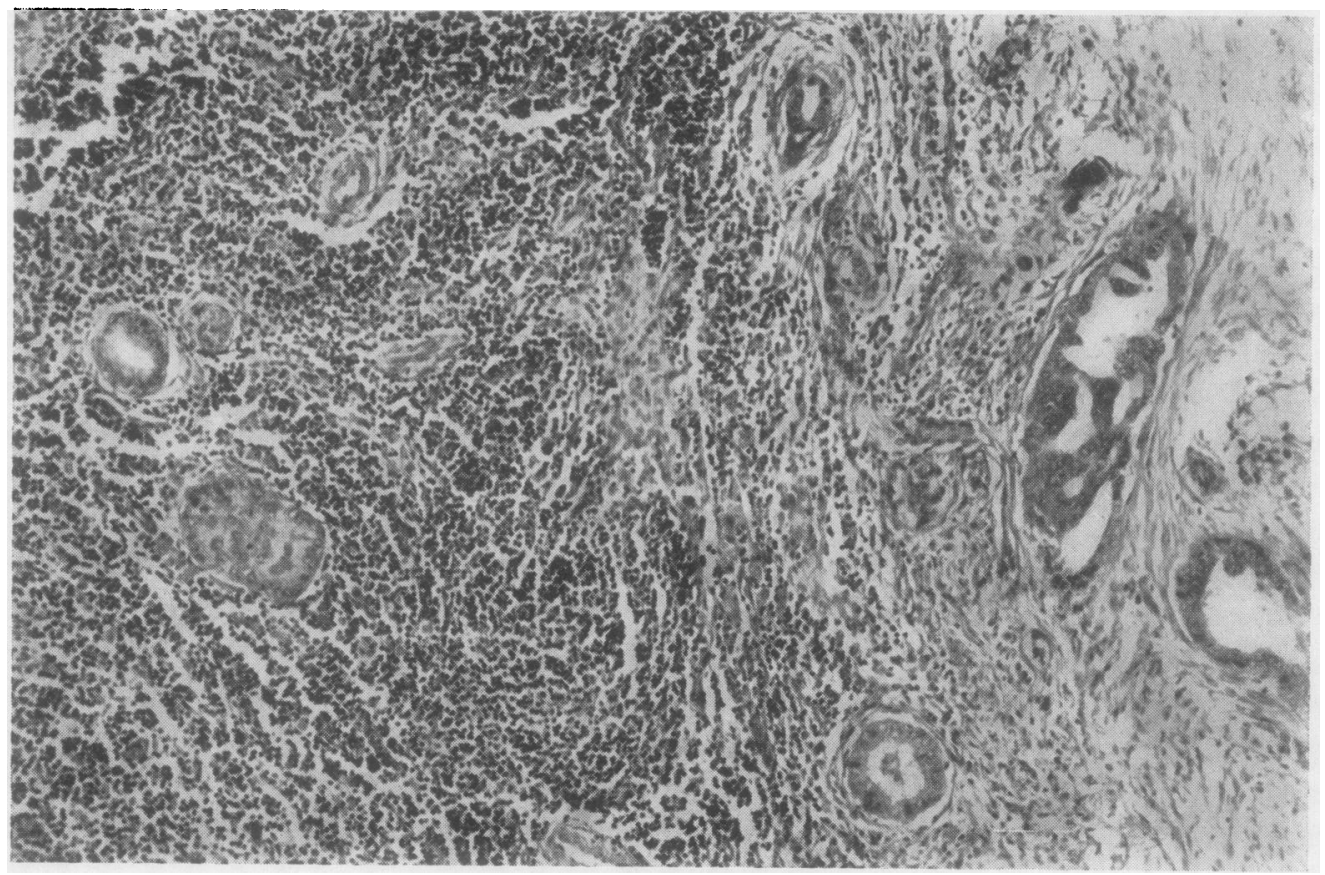

FIG. 8. Case 15, Table I. Carcino-sarcomatous recurrence in an axillary lymph node of the tumour shown in Fig. 6. Carcinomatous glands are penetrating the lymphoid tissue (left) ahead of the main tumour mass (right) which is a mixture of fibrosarcoma and adenocarcinoma. (Haematoxylin and eosin $\times 90$.)

other 38 cases were lymph nodes found to be involved.

ADENOFIBROSARCOMAS

WITH SOLITARY LUNG METASTASIS FOUR AND A HALF YEARS LATER A woman of 64 (Case 20, Table II) presented with a lump in the right breast which had been growing for five months. On examination it was 'the size of an orange' and situated in the upper outer quadrant. There were attachments to the skin and deep structures, and the overlying skin was inflamed. A radical mastectomy was performed. The tumour was a firm, apparently encapsulated mass, $6 \mathrm{~cm}$. diameter. Microscopy showed that it was a fibrosarcoma in which were embedded many glands (Fig. 9). The sarcomatous tissue surrounding some of these ducts was remarkably basophilic (Fig. 10) and sometimes resembled hyaline cartilage (Fig. 11). Necrosis was extensive. The axillary nodes were free of tumour. The patient remained well for four years, but four and a half years after the operation she returned to hospital with a history of loss of weight of $14 \mathrm{lb}$. in the previous six months. The mastectomy scar and the left breast were normal but a chest radiograph showed a single rounded shadow in the right lung for which pneumonectomy was performed. The excised lung contained a solid tumour which replaced the middle lobe. Histologically this was a well-differentiated spindle-cell sarcoma lacking epithelial elements. The patient died four days after operation. At necropsy there were no other deposits and death had been caused by multiple thrombi in the pulmonary arteries.

On clinical grounds this patient was thought to have a carcinoma of the breast and therefore a radical mastectomy was done. This may be why there was no recurrence in the mammary area and 3 . perhaps also why metastatic recurrence was delayed $\delta$ for four and a half years. On the other hand, the fact that metastasis took the form of a solitary, welldefined mass which was easily resected suggests that the tumour was not highly invasive and therefore less liable to produce multiple secondaries.

WITH TWO LOCAL RECURRENCES A woman of 58 (CaSe 22, Table II) reported with a lump in the right breast $\mathrm{N}$ which had been present for one month and which, $\omega$ though hard, was mobile. Simple mastectomy was performed. Microscopy of the excised tumour $(6 \mathrm{~cm}$. dia- 6 meter) showed a spindle-cell sarcoma with fairly scanty $\frac{}{\mathrm{D}}$ epithelial elements. The patient remained well for some $\stackrel{\mathscr{S}}{+}$ six months but within nine months of the operation a $T$ mass $5.5 \mathrm{~cm}$. diameter had developed at the operation $\bar{O}$ site. This was excised and microscopy revealed a some- $\overrightarrow{\mathbb{D}}$ what higher degree of malignancy. Two months after $\frac{\mathcal{O}}{1}$ this episode she developed another recurrence in the $\unrhd$ sutcutaneous tissue above the operation scars, and $\underset{\sigma}{\sigma}$ 
TABLE II

ADENOFIBROSARCOMAS

\begin{tabular}{|c|c|c|c|c|c|c|c|}
\hline No. & $\begin{array}{l}\text { Age of } \\
\text { Patient } \\
\text { (yr.) }\end{array}$ & $\begin{array}{l}\text { Length of } \\
\text { History }\end{array}$ & $\begin{array}{l}\text { Relation } \\
\text { to } \\
\text { Menopause }\end{array}$ & Site & $\begin{array}{l}\text { Macroscopic } \\
\text { Appearance and } \\
\text { Size }\end{array}$ & Histology & $\begin{array}{l}\text { Treatment and } \\
\text { Post-operative Course }\end{array}$ \\
\hline 17 & 78 & $\begin{array}{l}10 \mathrm{mth} . \\
\text { slow, then } \\
\text { rapid growth }\end{array}$ & After & $\begin{array}{l}\text { Lower left } \\
\text { inner } \\
\text { quadrant }\end{array}$ & $7.5 \mathrm{~cm}$. diameter & $\begin{array}{l}\text { Spindle-cell and giant } \\
\text { cell sarcoma }\end{array}$ & $\begin{array}{l}\text { Radical mastectomy } \\
\text { Local recurrence } 3 \\
\text { months later }\end{array}$ \\
\hline 18 & 67 & $2 \mathrm{mth}$. & After & Left & $4 \mathrm{~cm}$. diameter & $\begin{array}{l}\text { Sarcoma with giant cells } \\
\text { and osteoid and bone } \\
\text { formation; squamous meta- } \\
\text { plasia in epithelium }\end{array}$ & Radical mastectomy \\
\hline 19 & 67 & $4 \mathrm{mth}$. & After & Outer right & $\begin{array}{l}\text { Tense and cystic, } \\
12 \mathrm{~cm} \text {. diamerer }\end{array}$ & Fibrosarcoma & $\begin{array}{l}\text { Simple mastectomy } \\
\text { Local recurrence and } \\
\text { death } 6 \text { months later }\end{array}$ \\
\hline 20 & 64 & $5 \mathrm{mth}$. & After & Right & $\begin{array}{l}\text { Firm, encapsulated } \\
\text { mass } 6 \mathrm{~cm} \text {. diameter } \\
\text { fixed to skin and } \\
\text { muscle }\end{array}$ & $\begin{array}{l}\text { Low-grade fibrosarcoma, } \\
\text { extensive necrosis, many } \\
\text { ducts }\end{array}$ & $\begin{array}{l}\text { Radical mastectomy } \\
\text { Solitary sarcomatous } \\
\text { metastasis in right } \\
\text { lung resected } 4 \frac{1}{2} \text { years } \\
\text { later } \\
\text { Death from pulmonary } \\
\text { artery thrombosis } \\
\text { (post-operative) }\end{array}$ \\
\hline 21 & 61 & $10 \mathrm{mth}$. & After & $\begin{array}{l}\text { Upper left } \\
\text { outer quadrant }\end{array}$ & & Spindle-cell sarcoma & Radical mastectomy \\
\hline 22 & 58 & $1 \mathrm{mth}$. & After & Right & $\begin{array}{l}\text { Round, well- } \\
\text { circumscribed and } \\
\text { fleshy, } 6 \mathrm{~cm} \text {. diameter }\end{array}$ & $\begin{array}{l}\text { Well-differentiated spindle- } \\
\text { cell sarcoma with only a } \\
\text { few ducts }\end{array}$ & $\begin{array}{l}\text { Simple mastectomy } \\
\text { Local recurrences } \\
\text { after } 9 \text { and } 11 \text { months } \\
\text { Radical mastectomy } \\
\text { after } 13 \text { months then } \\
\text { radiotherapy } \\
\text { No metastases } \\
\text { Well } 2 \text { years after first } \\
\text { operation }\end{array}$ \\
\hline 23 & 54 & $3 \mathrm{mth}$. & After & Right & $\begin{array}{l}\text { Firm, round, circum- } \\
\text { scribed, } 2 \cdot 5 \mathrm{~cm} \text {. } \\
\text { diameter }\end{array}$ & Fibrosarcoma & $\begin{array}{l}\text { Radical mastectomy } \\
\text { Well } 2 \frac{1}{2} \text { years later }\end{array}$ \\
\hline 24 & 50 & & After & & & $\begin{array}{l}\text { Osteochondrosarcoma with } \\
\text { ducts around edge }\end{array}$ & \\
\hline $25^{1}$ & 39 & $\begin{array}{l}21 \mathrm{mth} . \text { in- } \\
\text { active for } 20 \\
\text { mth. then rapid } \\
\text { growth for } 1 \mathrm{mth} \text {. }\end{array}$ & Before & Right & $\begin{array}{l}\text { Mobile tumour } \\
12.5 \mathrm{~cm} . \text { diameter }\end{array}$ & $\begin{array}{l}\text { Spindle-cell sarcoma with } \\
\text { giant cells and chondroid } \\
\text { areas }\end{array}$ & Radical mastectomy \\
\hline 26 & 34 & $6 \mathrm{mth}$. & $\begin{array}{l}\text { Before } \\
\text { (lactating) }\end{array}$ & Right & $\begin{array}{l}\text { Yellow, rubbery, } \\
\text { spherical tumour, } \\
8 \mathrm{~cm} \text {. diameter, } \\
\text { encapsulated }\end{array}$ & $\begin{array}{l}\text { Spindle-cell sarcoma with } \\
\text { giant cells in lactating } \\
\text { breast }\end{array}$ & Local resection \\
\hline 27 & & & & & $\begin{array}{l}\text { Solid, encapsulated, } \\
5 \mathrm{~cm} \text {. diameter }\end{array}$ & $\begin{array}{l}\text { Low-grade fibrosarcoma; } \\
\text { ducts around periphery }\end{array}$ & Simple mastectomy \\
\hline 28 & & & & & $\begin{array}{l}\text { Whole breast en- } \\
\text { larged }(20 \times 18 \times 12 \\
\mathrm{cm} .) \text { and replaced by } \\
\text { fleshy and cystic mass } \\
\text { A small firm tumour } \\
(1 \mathrm{~cm} \text {. diameter }) \text { in } \\
\text { centre of mass }\end{array}$ & $\begin{array}{l}\text { Spindle-cell sarcoma, } \\
\text { small abscesses }\end{array}$ & Radical mastectomy \\
\hline
\end{tabular}

${ }^{1}$ On waiting list for 20 months to have 'fibroadenoma' removed before sudden growth necessitated admission

finally, 13 months after the first operation a radical mastectomy was performed. The excised breast contained a firm tumour, $3 \mathrm{~cm}$. diameter, which had invaded the pectoral muscles and histologically was a spindle-cell sarcoma. There was no evidence of chest secondaries. Radiotherapy was given to the mammary area postoperatively. Ten months after the radical mastectomy (23 months after the first operation) the patient was well, with no evidence of local recurrence or of metastasis.

Histologically this was a sarcoma of moderate malignancy, and the subsequent behaviour of the tumour was in keeping with this interpretation; there have been two local recurrences but, so far, no distant metastasis. 


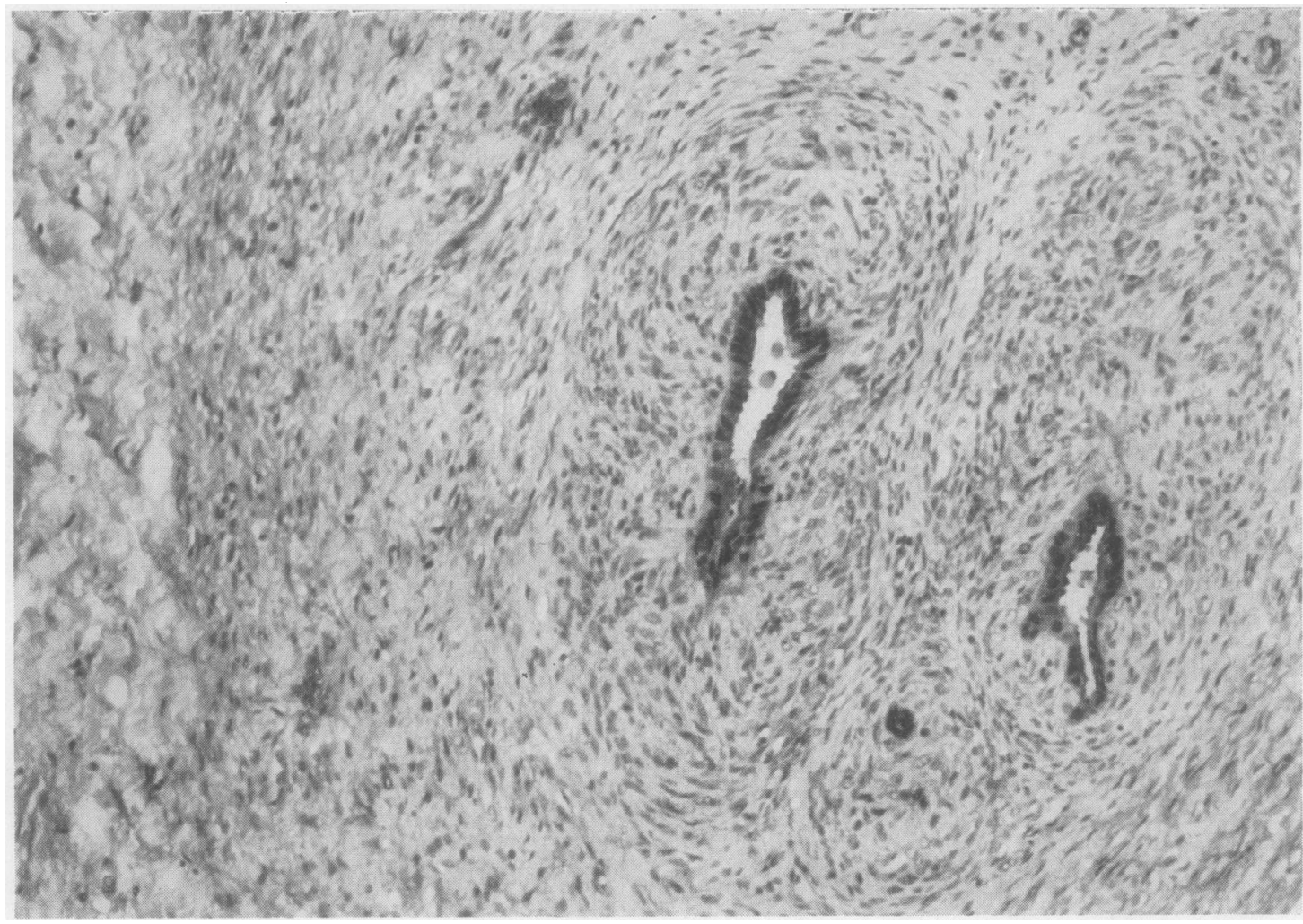

FIG. 9. Case 20, Table II. At the left is a layer of densely fibrous normal breast stroma. The rest of the tissue is adenosarcoma. Note the way the sarcoma cells are orientated round the acini. (Haematoxylin and eosin $\times 90$.)

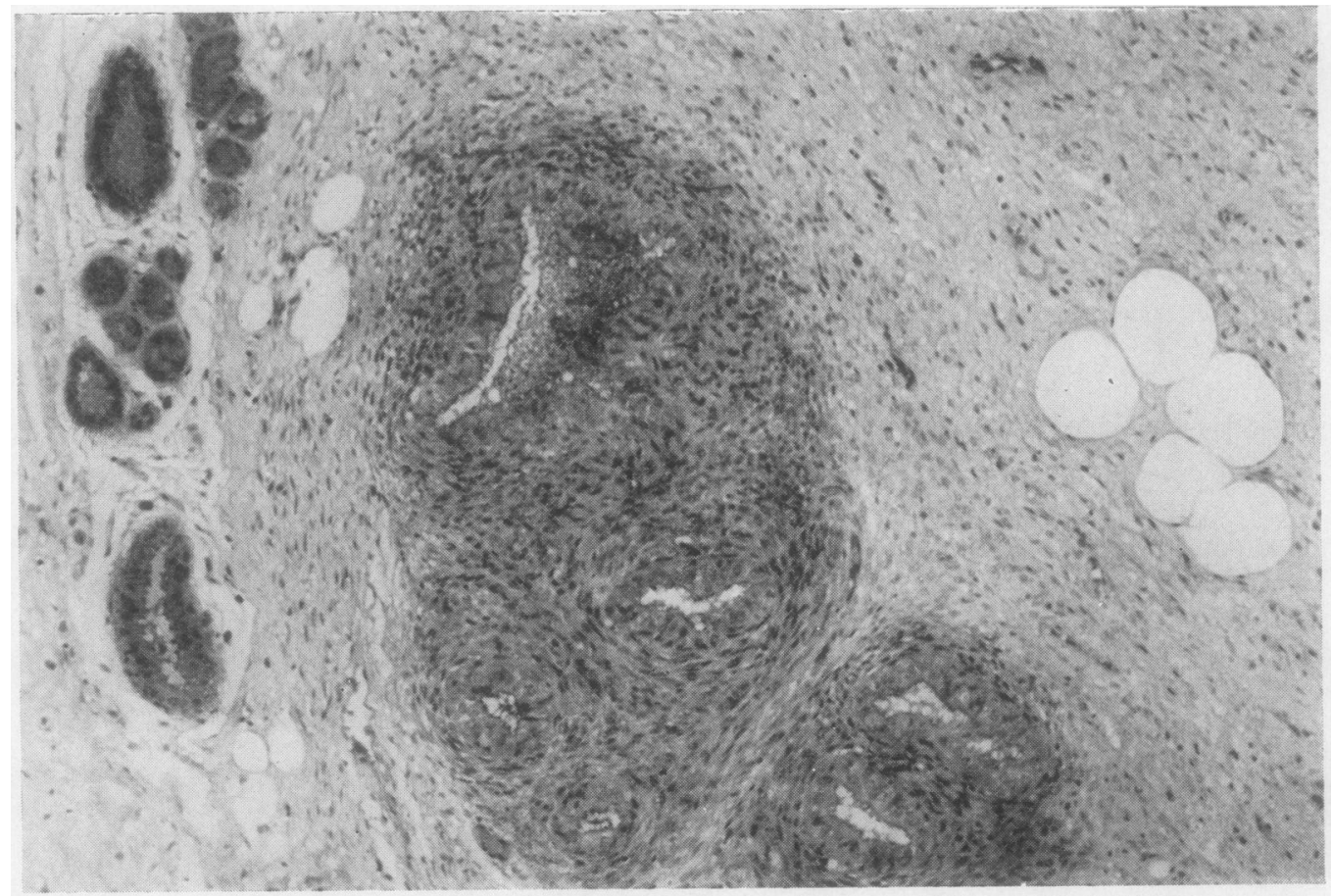

FIG. 10. Case 20, Table II. A group of normal breast ductules (left) are being compressed by the growing edge of the $\mathcal{O}_{0}$ adenosarcoma. The sarcomatous tissue is more cellular and basophilic around the glandular elements of the tumour (centre). (See also Fig. 11.) (Haemxtoxylin and eosin $\times$ 90.) 


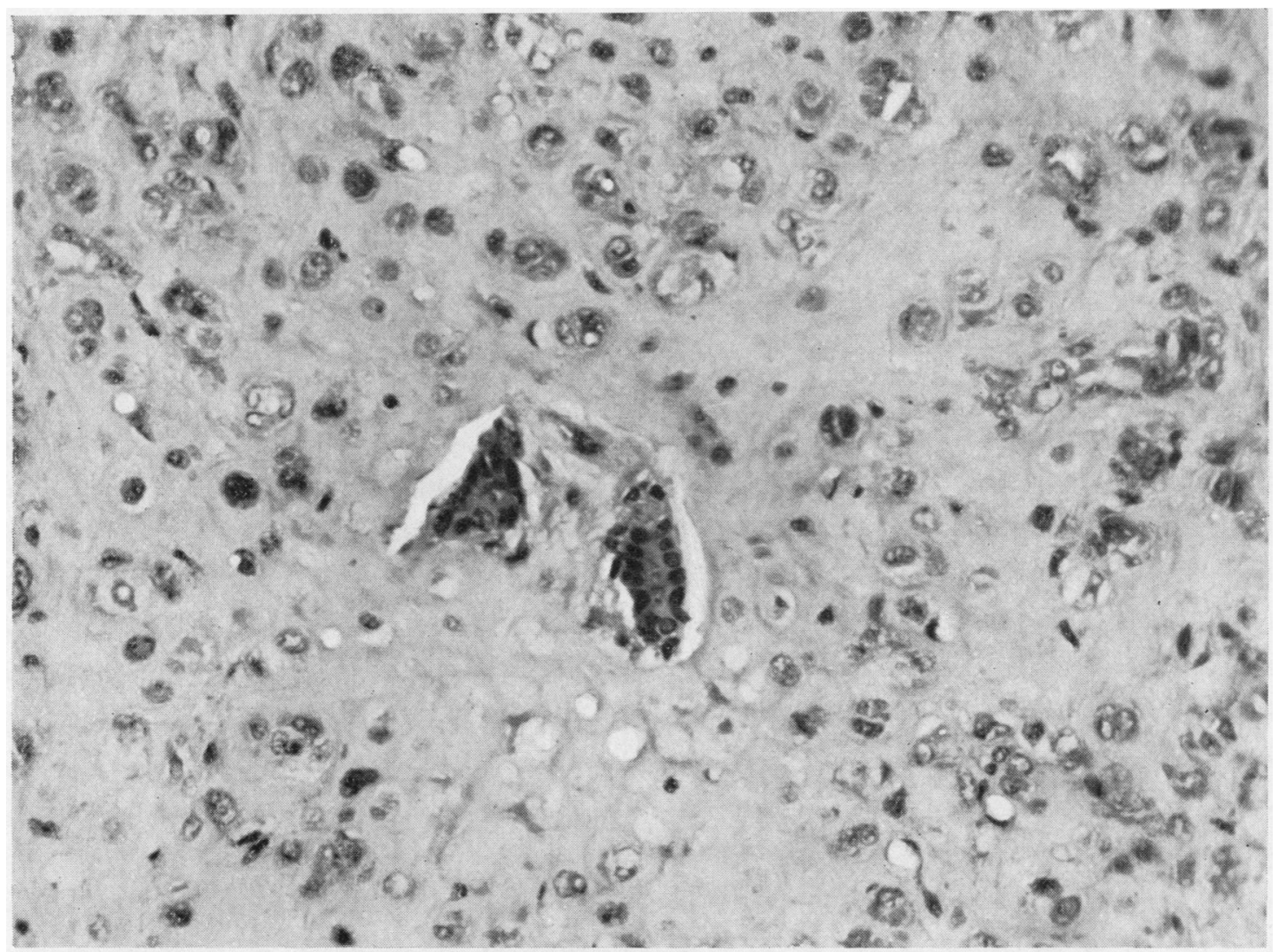

FIG. 11. Case 20, Table II. Adenosarcoma showing two very abnormal acini (centre) surrounded by sarcomatous tissue which closely resembles hyaline cartilage. (Haematoxylin and eosin $\times 140$.)

\section{'PURE' SARCOMAS}

FIBROMYXOSARCOMA WITH DEATH FROM SARCOMATOSIS A woman of 62 (Case 33, Table III) had noticed a lump in the right breast 16 weeks previously. The lump had slightly increased in size during the six weeks before she reported but she had no pain or discharge from the nipple. A lump was visible in the lower quadrant of the right breast below the nipple. To palpation it was the size of a walnut, hard and craggy and fixed to skin but not to muscle. No glands were palpable and the nipple was not retracted. The left breast was normal. Radical mastectomy was performed. The outer lower quadrant of the operation specimen contained a spherical mass $4 \mathrm{~cm}$. diameter, which, though of hard consistence, showed irregular translucent gelatinous areas on cross section. The tumour adhered to the skin over an area about $15 \mathrm{~mm}$. diameter. No enlarged lymph nodes were found. Histologically, the tumour was a fibromyxosarcoma invading the surrounding breast and fatty tissues as well as the subcutaneous tissue. There was extensive necrosis.
Noteworthy was the intense infiltration of the invading edge of the tumour by eosinophil leucocytes. Postoperative radiotherapy was given. The patient died one year after the operation; necropsy showed sarcomatosis.

This is a more malignant form of breast sarcoma. Despite the comparatively small size of the primary growth, radical removal of the breast and radiotherapy failed to save the patient who died of sarcomatosis within a year. All the same, it is noteworthy that no secondary deposits were found in the axillary nodes in the operation specimen, despite the invasiveness of the tumour.

OSTEOCHONDROSARCOMA WITH DEATH FROM SARCOMATOSIS Ten days before reporting, a woman of 52 (Case 37, Table III) discovered a lump in the left breast when washing herself. She had no pain or discharge from the nipple. Her health had been good and her weight steady. She had two children and had had no lactation troubles. The 
TABLE III

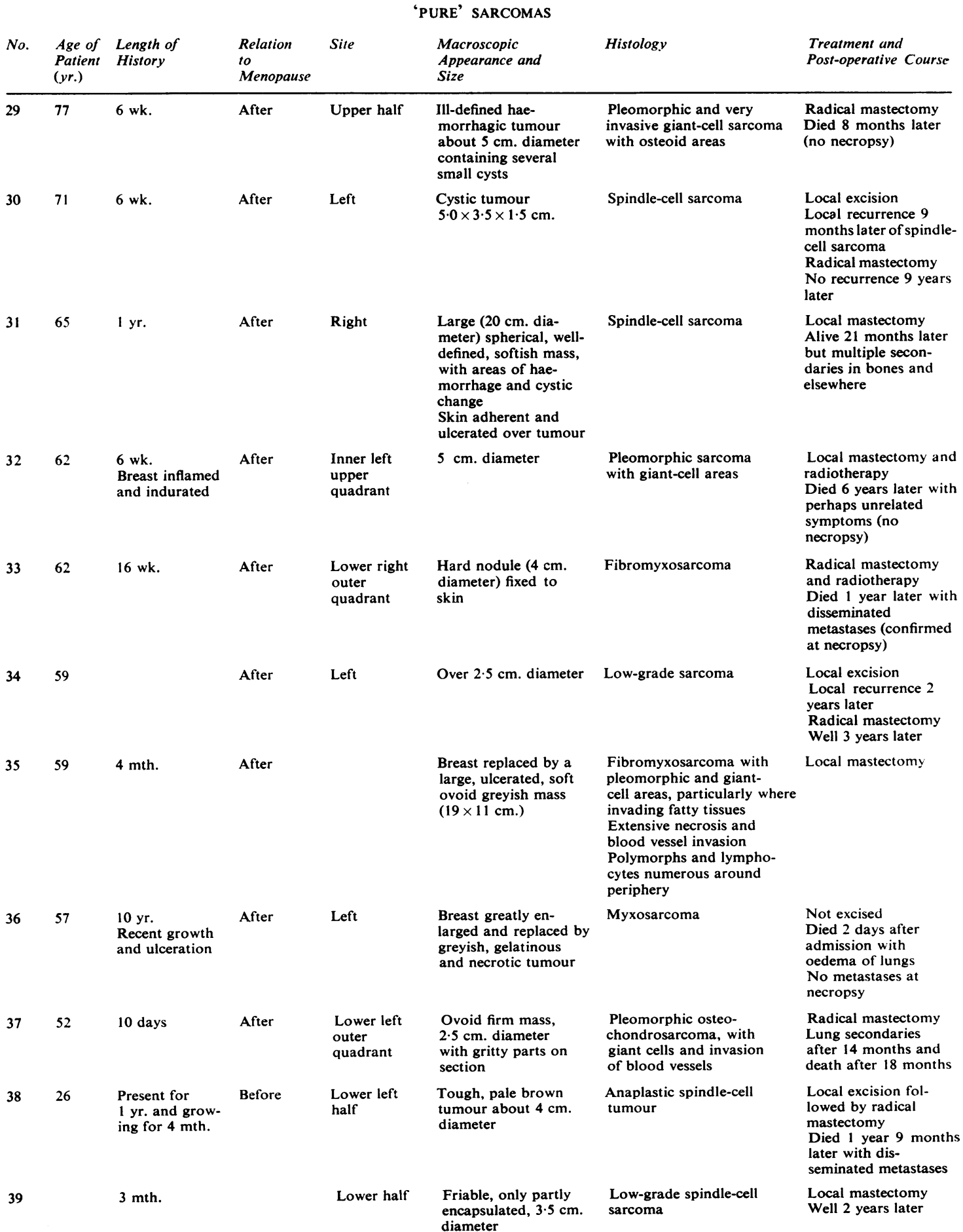




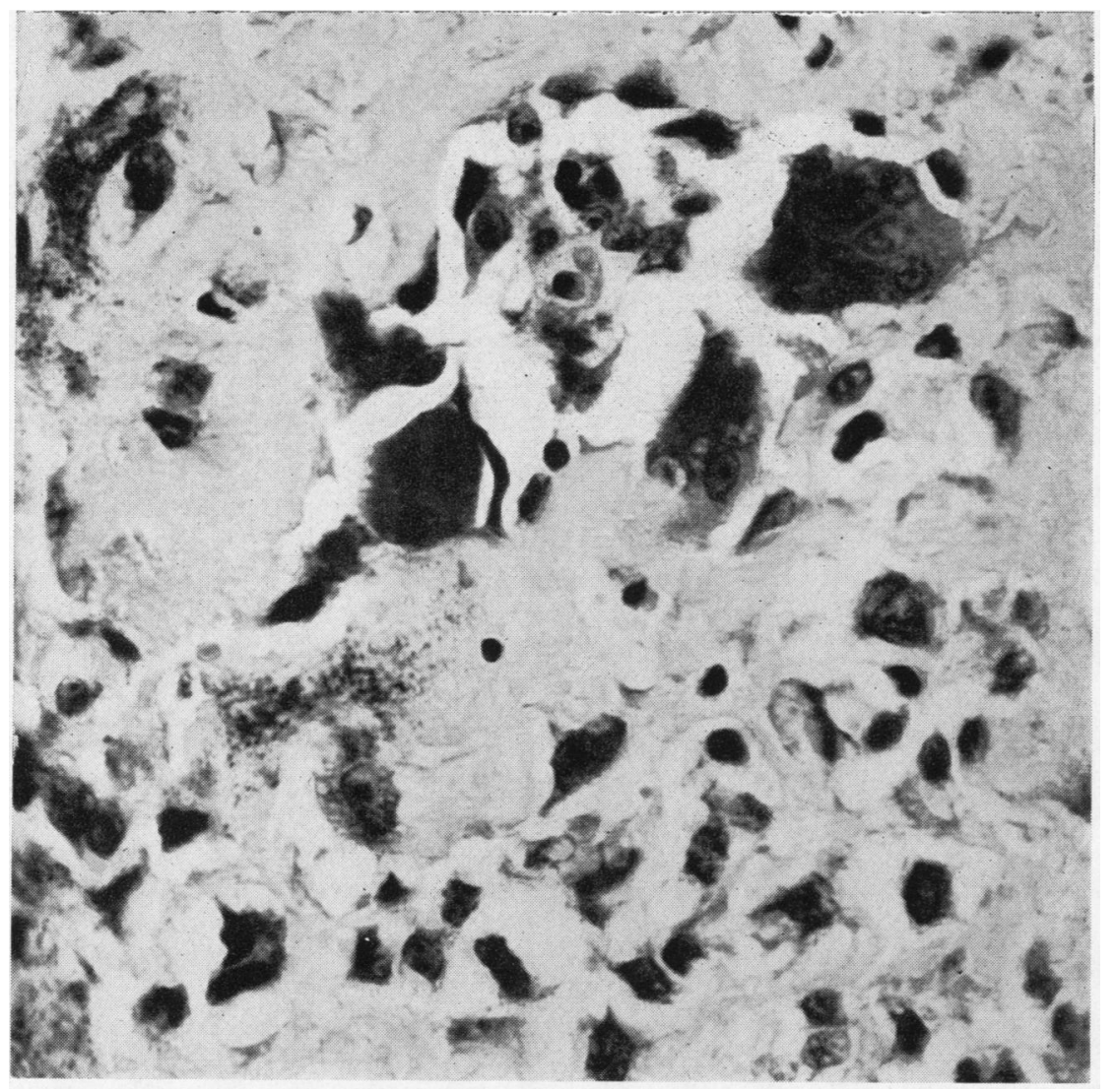

FIG. 12

FIG. 12. Case 36, Table

III. The very pleomorphic tumour cells, some multinucleate (centre), are forming abundant osteoid. In one area (below left of centre), this is calcifying. (Haematoxylin and eosin $\times$ 400.)

FIG. 13. Case 36, Table III. The tumour cells have undergone cartilaginous metaplasia. (Haematoxylin and eosin $\times$ 400.)

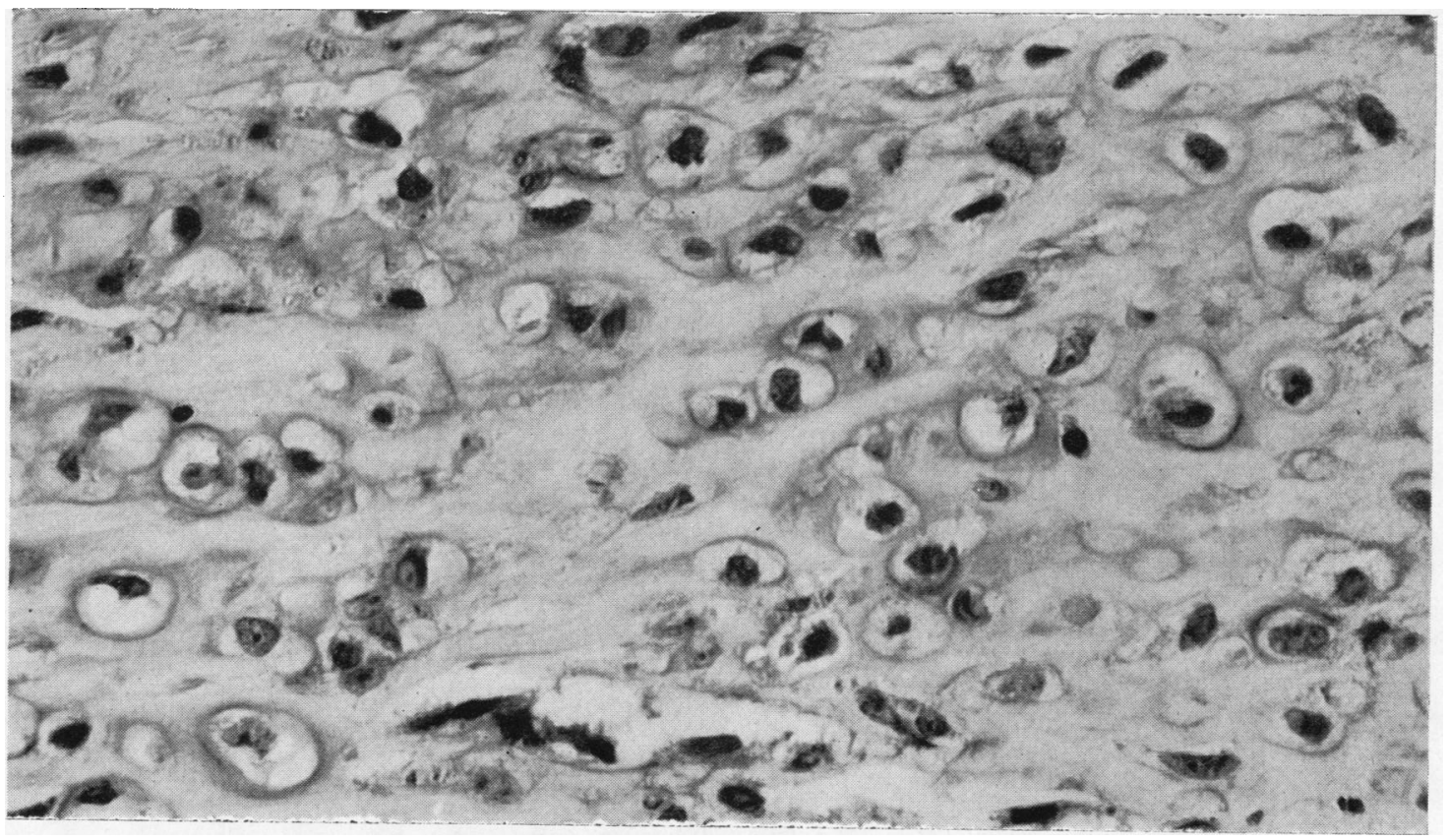


breast was of normal shape but contained an elongated lump with lobulated surfaces in the lower outer quadrant. It was not tender or adherent to skin or to the deep tissues. No axillary or infraclavicular lymph glands were palpable. Radical mastectomy was performed.

The tumour was ovoid and measured about $2.5 \mathrm{~cm}$. in its long axis. It was partly cystic. The solid parts cut with a gritty sensation. There was no definite capsule. Histologically, the specimen was an osteochondrofibrosarcoma (Figs. 12 and 13). Cellular pleomorphism was great and many giant cells, some resembling osteoclasts, were present. There were groups of tumour cells within many blood vessels. Necrosis was extensive. Death from sarcomatosis occurred 18 months after operation.

This is another example of highly malignant breast sarcoma: the tumour was small, it was noticed only 10 days before operation, treatment was radical, but disseminated secondaries were detected within about a year of operation and death occurred a few months later. This outcome was readily forecast from the histological features and particularly by the widespread vascular penetration by growth. The tumour's complex structure also illustrates the metaplastic potentialities of breast mesenchyme.

\section{DISCUSSION}

\section{AGE INCIDENCE}

The ages of these 39 cases of sarcoma ranged from 26 to 78 years, but the majority were in elderly women. Few long antedated the menopause, and the one which did do (Case 38, Table III) is much the least satisfactory of the whole series, in that the patient, a woman of 26 , had been exposed for some years to oestrogens in the course of her employment in a drug-making factory, and anaplasia of the tumour cells was so complete that the possibility of her having spindle-cell carcinoma cannot be excluded.

\section{INCIDENCE}

There is uncertainty over the frequency with which sarcoma of breast occurs. Illingworth and Dick (1941) put it as high as $3 \%$ of all mammary tumours, whereas Willis (1948) diagnosed it only once among 698 breast tumours. Our experience suggests that the true figure is somewhere between those extremes. Thus eight of the 39 cases occurred in the last 10 years in one hospital, and during the same period there were 868 carcinomas of breast, that is, the eight sarcomas formed $0.9 \%$ of all malignant breast tumours. Undoubtedly, the widely varying estimates of incidence are at least partly accounted for by the vagueness of the term 'malignancy'. Most breast sarcomas are of moderate malignancy by any criteria, and since the large majority are curable by adequate surgery, a certain latitude in the interpretation of the histological features is permissible without serious repercussions. It must be made clear therefore that in all but a few of the present series of cases the features of malignancy were unmistakable on microscopy; and the few which did not possess such a histological structure (Cases 3 and 4, Table I) were malignant clinically. The larger matter of the histogenesis of sarcoma of breast also bears on this question of incidence.

\section{HISTOGENESIS}

Probably the most important clue to the histogenesis of at least a significant proportion of breast sarcomas is provided by Table I which lists those tumours which undoubtedly developed from fibroadenomas, and by Table II, which lists the tumours with an adenosarcomatous structure. Fibroadenomas generally arise in younger women and seem to be hormone-dependent to a certain extent as most of them tend to regress after the menopause. However, Table I shows that some fail to do so and start to grow in an aggressive way. Although this new growth is primarily on the part of the fibroadenoma's connective tissue, the epithelium is very often involved too, for the malignant parts of many of the tumours listed in Table I contained glandular elements which appeared to be integral parts of the new tissue, that is, they were adenosarcomas. In fact, in several cases the abnormal shape of the glands and the pleomorphism and mitotic activity of the epithelial cells (Fig. 5) suggested carcinoma. But the only certain example of carcinomatous transformation of the epithelial element was provided by Case 15 (Table I) where the axillary lymph-node metastasis contained both epithelial and mesenchymal components (Fig. 8). The relationship between breast epithelium and its supporting stroma is very intimate, and the fibroadenoma is a true 'mixed' tumour. It is hardly surprising therefore that adenosarcomatous and even carcinosarcomatous transformation should occur in a fibroadenoma of breast. What is remarkable is the way the epithelium and connective tissue remain together, even to the extent of metastasizing to a lymph node (Fig. 8).

As fibroadenomas occasionally undergo adenosarcomatous change the adenosarcomas listed in Table II might well have originated in pericanalicular fibroadenomata. If they did not, one must postulate either that sarcomatous breast tissue has a marked tendency to induce the epithelium to grow along with it or that the unknown carcinogen produces simultaneous malignant change in connective tissue and epithelium. 
With regard to the 'pure' sarcomas (Table III), experience with the cases listed in Tables I and II suggests that the more closely these are examined, the greater is the proportion found to contain epithelial elements. Another feature which tends to link this group with many of the tumours in Tables I and II is their marked tendency to be myxosarcomatous.

Lastly, it is probably significant that breast sarcoma is a tumour of the 'carcinoma age' group. In this it is reminiscent of such 'secondary' sarcomas as osteogenic sarcoma developing in bones affected by Paget's disease or of leiomyosarcoma arising from a uterine fibromyoma. By analogy breast sarcoma may well be a 'secondary' type of growth.

\section{TERMINOLOGY}

The terminology of breast conditions is notoriously confused and several other terms might be applied to some of the tumours described in this paper. One is 'giant' fibroadenoma. Fibroadenomas occur in all sizes, and, understandably, many pathologists have labelled as 'giant' those tumours, pericanalicular and/ or intracanalicular in type, which struck them as unusually large. However, the term was given a more specific meaning by Treves and Sunderland (1951) when they stated that the essential feature of a giant fibroadenoma is the disproportionate growth of the mesenchymal component (Fig. 1); that is, the term 'giant' should refer only to the relative size and cellularity of the intracanalicular 'clubs' or processes. Naturally, most giant fibroadenomas are large tumours, but small ones $(1$ or $2 \mathrm{~cm}$. diameter) possessing such giant processes do occur. There is much to be said for Treves and Sunderland's usage, but unfortunately there is little doubt that pathologists will continue to use giant to describe the size of a tumour and even to apply it to unusually large pericanalicular fibroadenomas.

Giant fibroadenomas in the strict sense of the term may be simple or malignant and the malignant ones form a substantial fraction of all breast sarcomas. Ten of the 16 tumours in Table I qualify as giant fibroadenomas, and these therefore constitute about $25 \%$ of the present series of 39 sarcomas. Six of these 10 cases occurred in 20 years in one of the three hospitals concerned in the present study. During the same period there were in the same hospital 11 other patients with tumours which were histologically benign or of doubtful malignancy and which are therefore not included in Table I. Incidentally, the reasons for not including at least some of these 11 neoplasms in Table I must be arbitrary and personal to a certain extent; but at least the patients have had no subsequent trouble after only local excision of the tumour. These figures also give some idea of the frequency with which giant fibroadenomas are encountered and of the relative proportions of benign and malignant forms; but the figures are very approximate indeed, since it is obviously impossible to lay down criteria, clinical and/or histological, which will readily distinguish between the benign and malignant forms of giant fibroadenomas, and it is wise to regard all with suspicion. Fortunately, with adequate surgery, most will not justify these suspicions, and even an enormous ulcerated specimen may fail to provide histological or post-operative evidence to justify a diagnosis of sarcoma (Goodall and Curran, 1953).

Cystosarcoma phyllodes is an old term (Müller, 1838) which still confuses surgeons and pathologists. Müller originally applied it to tumours which showed a leaf-like or cabbage-like pattern when cut across. This characteristic appearance results from great overgrowth of the intracanalicular processes of a fibroadenoma, so that large fibromyxomatous masses form which are separated by epitheliumlined, slit-like crevices. Thus the term is roughly synonymous with the giant fibroadenoma of Treves and Sunderland, except that the intracanalicular growths should be sufficiently large and numerous for the characteristic leaf-like pattern to be readily visible to the naked eye. Müller did not assess the malignancy of his tumours histologically but relied only on their gross appearance and clinical behaviour, and so there was no correlation with microscopic structure. It is not surprising therefore that his term has been used very loosely and applied to tumours of widely varying histological appearance (for review, see Goodall and Curran). Perhaps the most useful feature of the term lies in its ominous sound, which serves as a warning that tumours with this naked-eye structure should not be treated too lightly! However, only a minority of breast sarcomas are 'cystosarcomatous' and the majority of 'phyllodes' type tumours behave benignly. In other words, the term is a source of confusion and it should be discarded. So, incidentally, should the term 'Brodie's serocystic disease', which is equally vague.

\section{TREATMENT AND PROGNOSIS}

It is noteworthy that of the 17 patients who had radical mastectomy either at the initial operation or for a recurrent growth, only one had secondary deposits in the axillary lymph nodes, and this single exception was a very unusual tumour indeed, a carcinosarcoma (Case 15, Table I). This fact probably illustrates the reluctance of sarcomas to use the lymphatic route for metastasis and suggests that 
simple mastectomy is sufficient treatment for sarcoma of breast. There seems to be little point, therefore, in doing a radical mastectomy unless the epithelial elements in the tumour appear to be frankly carcinomatous, an occurrence so uncommon (Case 15, Table I) as to be discounted when considering treatment. Simple mastectomy does not, of course, eliminate the possibility of later bloodborne metastasis, since even radical mastectomy failed to save several women from death from disseminated metastases. By and large, however, breast sarcoma does not metastasize readily and even when it does the metastases may be solitary and resectable (Case 20, Table II). On the other hand, metastasis may appear after a considerable interval (Case 4, Table I). Although radical mastectomy is therefore probably not necessary, inadequate primary operations must be avoided, for a considerable proportion of those cases treated by local excision had local recurrences (for example, Cases 19 and 22, Table II), sometimes after several years (Case 10, Table I).

\section{PARITY AND MARITAL STATE}

On the incomplete data available, neither of these factors seems to have a connexion with the appearance of breast sarcoma.

\section{ASSESSMENT OF MALIGNANCY}

As already stated, the fact that most breast sarcomas are curable by adequate surgery must account in part at least for the wide variation in the frequency with which the diagnosis of sarcoma is made, since retrospective correction of the diagnosis is rarely required. Even with care, however, histology is not an infallible guide with the types of tumour listed in Tables I and II. Thus several tumours proved clinically malignant despite the pathologists' inability to demonstrate, even in retrospect, a firm histological basis for their behaviour, the most striking example being provided by Case 4 (Table I), a patient who died from sarcomatosis four years after mastectomy for a large 'fibroadenoma' (Collins and Dodge, 1959). Several reasons for this discrepancy can be suggested. Where the tumour has developed from a fibroadenoma, only a part of the fibroadenoma's 'stroma' may have undergone malignant change, and this part may be readily missed when relatively few blocks are taken for histology. Many of these sarcomas invade the tissues on a very broad front and often acquire a dense but incomplete fibrous 'capsule' (Figs. 4, 9, and 10) which can mislead the careless observer. In addition breast sarcomas tend to be noticeably mucoid macroscopically and myxomatous histologically; and myxomatous tumours are notoriously unpredictable. Willis (1948) believes, in fact, that it is not worthwhile trying to distinguish between myxoma and myxosarcoma and that all prominently myxomatous tumours should be regarded as malignant. Probably the most important factor of all, however, is the tendency for the pathologist to regard as invariably benign anything even vaguely resembling a fibroadenoma and to ignore quite definite histological evidence of malignancy. 'Pure' sarcomas (Table III) give him little trouble, on the other hand, although he may fail to realize that a small minority of breast sarcomas are very invasive and are able to kill within a remarkably short period of time.

With regard to prognosis, the significance of bone or osteoid in the tumour is uncertain. Admittedly they were present in two of the three rapidly-fatal cases (Cases 29, 33, and 37, Table III) but they were also present in four other cases (Case 9, Table I and Cases 18, 24, and 25, Table II), of which only one has had a reasonably long follow-up (Case 9, Table I), so far with no signs of recurrence. As might be expected, invasion of blood vessels was prominent in those tumours which exhibited the greatest degree of clinical malignancy (e.g., Cases 29 and 37, Table III).

There is no apparent connexion between prognosis and either the size of tumour at operation or the length of time it had been known to be present before operation.

We are indebted to the clinicians of the Royal Infirmaries of Glasgow and Sheffield and of St. Thomas's Hospital, London, for allowing us to use their records; to Dr. Van der Merwe of the General Hospital, Burton-onTrent, for Case 5; and to Miss J. Read for secretarial help.

\section{REFERENCES}

Collins, P. G., and Dodge, O. G. (1959). Brit. J. Surg., 47, 37. Goodall, A. L., and Curran, R. C. (1953). Ibid., 40, 479. Illingworth, C. F. W., and Dick, B. M. (1941). A Text-book of Surgical Pathology, 4th ed., p. 382. Churchill, London.

Müller, J. (1838). Ueber den feinern Bau und die Formen der krankhaften, Geschwülste., p. 56. Reimer, Berlin.

Treves, N., and Sunderland, D. A. (1951). Cancer, 4, 1286.

Willis, R. A. (1948). Pathology of Tumours, 1st ed., pp. 210 and 654. Butterworth, London. 


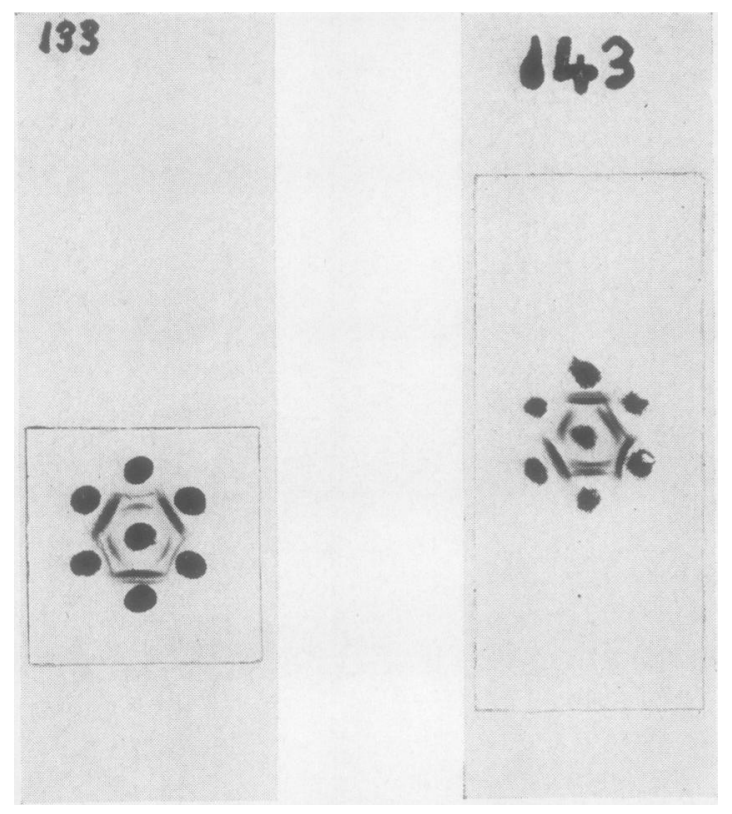

FIG. 3. Examples of finished preparations, stained with $0.5 \%$ azocarmine.

\section{SUMMARY}

A micro agar-gel precipitation technique is described in which the reagents are applied to the agar by means of a block of perspex through which holes have been drilled. The method allows a high degree of precision in placing the reagents on the agar with consequent good repeatability of results.

\section{A method for obtaining concentrates of eosinophils from blood}

\author{
R. F. ALEXANDER AND A. I. SPRIGGS From the \\ Churchill Hospital, Oxford
}

In a previous publication (Spriggs and Alexander, 1960) we described an albumin gradient method for separating the different white cells of blood. This was applied to the isolation of tumour cells but it was also noted that very pure suspensions of neutrophil polymorphonuclears could be obtained by the same method. It has now been found that the eosinophil leucocytes can be collected by the albumin method in a separate layer, and if the blood sample comes from a patient with eosinophilia it is sometimes possible to pipette these cells off in a high degree of purity.

The albumin gradient method need not be described again, but it should be noted that all equipment must be siliconed. The cells form a series of layers according to their specific gravity, as shown in Fig. 1. The platelets

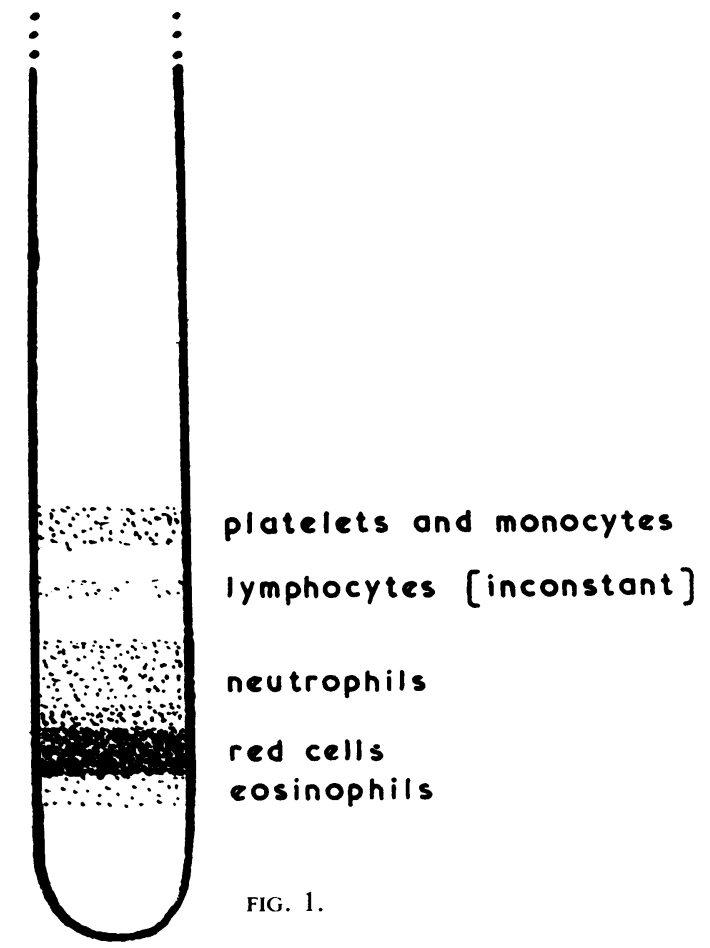

are on top, with most of the leucocytes below them, and any residual red cells not removed by the preliminary sedimentation are lower still. When eosinophils are Received for publication 20 July 1961. 